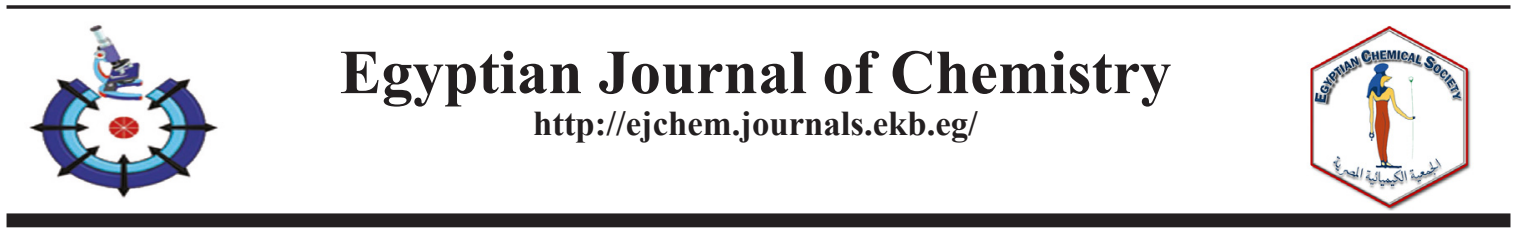

\title{
Improvement of Dyeing and Antimicrobial Properties of Cotton Fabrics through Pre-treatment with Silver Nanoparticles
}

\author{
Elshimaa H. Gomaa ${ }^{1}$, Nora M. Hilal ${ }^{1,2}$, Samia A. Abo Faraha ${ }^{1}$ \\ ${ }^{1}$ Chemistry Department, Faculty of Science, Al-Azhar University (Girls), Nasr City, Cairo, \\ Egypt \\ ${ }^{2}$ Science \& Technology Department, College of Ranyah, Taif University, KSA
}

\begin{abstract}
OILVER nanoparticles have been synthesized by chemical reduction of silver salt solution, characterized by its surface plasmon resonance peak in absorption spectra at $425 \mathrm{~nm}$. The studies were carried out by scanning electron microscopy (SEM), transmission electron microscopy (TEM), energy dispersive X-ray analysis (EDX) and fourier transform infrared spectroscopy (FTIR). The size and size distribution of these nanoparticles have also been examined using particle size analyzer, the average size of the particles is found to lie between $5 \mathrm{~nm}$ and 50 indicated the presence of micrometer-size conglomerates composed of much smaller particles. Chemical analysis performed with the use of EDX revealed that the powder contains about $72 \%$ of silver. The findings support the size and shape of the synthesized nano silver particles. These nanoparticles have been applied to cotton, by usual padding technique and manifested the improved microbial resistance. The dyeing behavior of the treated fabrics with reactive yellow 2 has been studied and the build-up of dye, measured as colour strength in terms of K/S values. The higher K/S values are obtained when the $\mathrm{Ag}$ nano is anchored in the fibre matrix. Improved colour strength with good wash and light fastness is also obtained after treatment of fabrics with nanoparticles.
\end{abstract}

Keywords: Dyeing, Cotton, Nanomaterials, Treated fiber reactive dye, Antimicrobial.

\section{Introduction}

Reactive dyes are widely used for the dyeing of cotton. These dyes are anionic in character and, in general, are water soluble due to the presence of sulphonic groups $\left(\mathrm{SO}_{3}^{-}\right)$in the chemical structure [1]. However, since cotton itself adopts an anionic surface charge in water, these dyes have low intrinsic affinity for the fibre. The repulsive charge between dye and cotton can be overcome, and increase in dye bath exhaustion.
Numbers of attempts have been made to modify the cotton fibre using compounds containing cationic groups. These are mainly quaternary ammonium salts or polymeric amines or amides. The application of silver nanoparticles to cotton is one of the most extensively studied because of its breathable, soft, comfort and other out standing attributes. Some researchers recently reported the possibility of utilizing silver nanoparticles for enhancement of the color strength and fastness properties of cotton based

*Corresponding author: Elshimaa Gomaa; e-mail: Alshimaa@azhar.edu.eg, atahelmy@yahoo.com Received 16/06/2019; Accepted 28/08/2019

DOI: $10.21608 /$ ejchem.2019.13705.1846

(C)2020 National Information and Documentation Center (NIDOC) 
fabrics and their antimicrobial properties [2]. Silver nano is a trademark name of an antibacterial technology which uses silver nanoparticels in washing machines, refrigerators, air conditioners, air purifiers and vacuum cleaners. Antimicrobial effect of silver nanoparticles on textiles has already been shown by various researchers [3]. Textile materials tend to act as a good medium for the growth and multiplication of microorganisms [4]. The basic chemical constituents, present in the natural fibers provide nutrition to microorganisms and thereby promote their growth. The growth of microorganisms in the textile materials cause innumerable problems such as unacceptable odor, loss of strength in fabric and stains and moreover, affect the health of the wearer. The major problem in health care especially in hospitals is the transmission of bacteria and pathogens from the patients to the workers and vice-versa through the textiles used by them[5].

The increasing concern towards health care has been a motivating factor for the production of antimicrobial textiles towards its direct applications in the environment safety and human health care application[6].

It is therefore important to impart antimicrobial effect on textile materials so as to protect the health of the wearer [7]. A number of antimicrobial agents have been used in textile applications. Of these silver nanoparticles have one of the best antimicrobial characteristics and cover a wide range of pathogenic microorganisms. They react with the sulfur-based proteins of the cell wall in microorganisms, inhibit with their metabolism, and thereby destroy them. Cotton has been effectively treated with silver nanoparticles to get the desired antimicrobial effects. Nanoparticles (1-100 nm) are increasingly used for biomedical applications due to their ability to sense and detect pathogens [8]. In the present work, Ag nanoparticles have been synthesized by the reduction of silver salt $\left(\mathrm{AgNO}_{3}\right)$ with tri-sodium citrate and characterized by particle size analyzer, scanning electron microscope (SEM), energydispersive spectroscopy (EDX) and Fourier transform infrared spectroscopy (FTIR). Prepared silver nano particles have been applied to textiles and the effect on various properties, like tensile, breaking load, crease recovery angle, bending length, dyeing and bacterial resistance, are examined by standard methods.

Egypt. J. Chem. Vol. 63, No. 4 (2020)

\section{Experimental}

Materials

Fabric

The cotton fabric (supplied by the Miser Helwan Company), having the specification was $140 \mathrm{~g} / \mathrm{m}^{2}$, warp 36 threads/cm, yarn count 30/1, weft 34 threads/cm, and yarn count 30/1

\section{Dyes and chemicals:}

Commercial reactive dyes, namely C.I. Reactive yellow 2, silver nitrate $\left(\mathrm{AgNO}_{3}\right)$, trisodium citrate $\left(\mathrm{C}_{6} \mathrm{H}_{5} \mathrm{O}_{7} \mathrm{Na}_{7} \cdot 2 \mathrm{H}_{2} \mathrm{O}\right)$. A stock standard solution of reactive yellow 2 at a concentration of $1000 \mathrm{ppm}$.

\section{Methods}

\section{Synthesis of silver nanoparticles :}

Silver nanoparticles were prepared by chemical reduction method[9,10]. All solutions were prepared in deionized water. $50 \mathrm{ml}$ of 0.001 $\mathrm{M}$ silver nitrate was heated to boiling using hot plate magnetic stirrer. To this solution $5 \mathrm{ml}$ of $1 \%$ tri-sodium citrate was added drop by drop. During this process solution was mixed vigorously. Solution was heated until color change is evident (yellowish brown).

Then it was removed from the heating element and stirred until cool to room temperature.

Mechanism of reaction could be expressed as follows:

$$
\begin{aligned}
& 4 \mathrm{Ag}^{+}+\mathrm{C}_{6} \mathrm{H}_{5} \mathrm{O}_{7} \mathrm{Na}_{3}+2 \mathrm{H}_{2} \mathrm{O} \longrightarrow 4 \mathrm{Ag}^{\circ}+ \\
& \mathrm{C}_{6} \mathrm{H}_{5} \mathrm{O}_{7} \mathrm{H}_{3}+3 \mathrm{Na}^{+}+\mathrm{H}^{+}+\mathrm{O}_{2} \uparrow
\end{aligned}
$$

Surface modification process of cotton fabrics using Ag nanoparticles:

The surface modification of cotton fabrics by Ag nanoparticles was achieved using a facile approach comprising of dip coating via stirring. Briefly, the cotton fabric $1 \mathrm{gm}$ was immersed into the solution containing $(0.25 \mathrm{gm}$ of $\mathrm{Ag}$ nanoparticles in deionized water) and allowed to vigorous stirring at $300 \mathrm{rpm}$ for $2 \mathrm{~h}$. After that, the Ag-coated fabric was taken from the solution and washed with deionized water for the removal of residual Ag nanoparticles on the surface. The resulting fabric was allowed to dry at room temperature. 


\section{Dyeing procedure:}

Untreated and treated cotton fabrics were dyed with reactive yellow 2 dye. 1000 ppm were applied with 30\% sodium sulphate followed by add sodium carbonate $30 \mathrm{~g} / \mathrm{L}$ with liquor ratio 1:50. The temperature was slowly raised to 60,75 , $90^{\circ} \mathrm{C}$ and dyeing was continued further $2 \mathrm{~h}$. then all the dyed samples were rinsed with water and dried at room temperature.

\section{Measurements and analysis}

\section{Color measurements:}

Color strength expressed as K/S was measured according to a previously reported method [11] using light reflectance technique, and the relative color strength was calculated by applying the following Kubelka-Munk equation.

Color strength $(\mathrm{K} / \mathrm{S})=(1-\mathrm{R})^{2} / 2 \mathrm{R}-\left(1-\mathrm{R}^{\mathrm{o}}\right)^{2} /\left(2 \mathrm{R}^{\mathrm{o}}\right)$

Where $\mathrm{R}$ and $\mathrm{R}^{\circ}$ are the decimal fraction of the reflectance of the colored and uncolored fabrics respectively; $\mathrm{K}$, the absorption coefficient; and $\mathrm{S}$, the scattering coefficient.

\section{Fastness properties :}

Fastness to washing, light and perspiration was assessed according to the standard methods [12] of AATCC technical manual, viz method 8 (1989) 68, 23(1993). Method 36 (1972) 68
(1993) 23; and Method 15 (1989) 68, (1993) 30 respectively.

\section{Evaluation of antimicrobial activity}

The untreated and treated samples were subjected to soil burial test as per AATCC test method 30-2004. After the stipulated period the samples were removed, washed with water and dried in air. The samples were than tested for breaking load on tensile tester.

Effect of AgNPs treatment on physical properties of cotton fabric.

The effect of silver (AgNPs) treatment on tensile strength, crease recovery and bending length has been studied. It is observed from Table (1) that the introduction of AgNPs into the structure of the fiber causes an improvement in the load bearing capacity of the fabric from 8.01 to $8.66 \mathrm{Kg}$ ). The AgNPs are small size can enter in between the polymer molecules and perhaps act as filler or crosslinking agent which also contribute to the load sharing phenomenon during load application to the material [2]. There is little improvement in crease recovery angle of cotton fabric (from 90 to 96) with a little increase in bending length (from 1.03 to 1.34 ) $\mathrm{cm}$. This observation proves that the particles penetrated in between the polymer chain molecules do not interfere much to the polymer flexibility of the system. The treatment is thus devoid of harshness to the material.

TABLE 1. Effect of AgNPs treatment on physical properties of cotton fabric.

\begin{tabular}{cccc}
\hline Sample & Breaking load, Kg & Crease recovery angle, deg & Bending length, cm \\
\hline Untreated cotton fabric & 8.01 & 90 & 1.03 \\
Treated cotton fabric & 8.66 & 96 & 1.34 \\
\hline
\end{tabular}

\section{Effect of AgNPs treatment on dyeing}

The AgNPs treated cotton fabric were dyed with reactive yellow 2 and compared with the untreated cotton fabric [2]. It is observed from table (2) that the $\mathrm{K} / \mathrm{S}$ values of the AgNPs pretreated cotton are higher than those of the corresponding untreated cotton fabric. The higher $\mathrm{K} / \mathrm{S}$ values of nanotreated cotton indicate that the presence of nano metal particles increases the dye affinity (from
7.05 to 16.47 ) towards the material. The negatively charged dye anions get attracted towards the fibre probably due to the polarity developed in the metal particles by induction which results in better bonding between the dye and the fibre. The better coupling of the dye and the fibre is also reflected in the improvement in the color fastness properties Table 3. Thus silver nano pretreatment not only improves the color strength but also improves the color fastness. 
TABLE 2. Effect of AgNPs on color strength of cotton fabric dyed with reactive yellow 2.

\begin{tabular}{lllllll}
\hline Sample & $\mathbf{L}^{*}$ & $\mathbf{a}^{*}$ & $\mathbf{b}$ & $\mathbf{d E}$ & $\mathbf{K} / \mathbf{S}$ & $\boldsymbol{\lambda}_{\max }$ \\
\hline Untreated cotton fabric & 73.36 & -0.58 & 65.72 & 65.48 & 7.05 & 415 \\
Treated cotton fabric & 28.72 & -6.61 & 10.30 & 54.30 & 16.47 & 410 \\
\hline
\end{tabular}

TABLE 3. Effect of AgNPs on fastness properties of samples dyed with reactive yellow 2.

\begin{tabular}{|c|c|c|c|c|}
\hline \multirow{3}{*}{ Sample } & \multicolumn{4}{|c|}{ Color fastness } \\
\hline & \multirow{2}{*}{ Wash } & \multirow{2}{*}{ Light } & \multicolumn{2}{|c|}{ Perspiration } \\
\hline & & & Acidic & Alkaline \\
\hline Untreated cotton fabric & $3-4$ & $3-4$ & $3-4$ & 4 \\
\hline Treated cotton fabric & $4-5$ & 5 & $4-5$ & $4-5$ \\
\hline
\end{tabular}

\section{Results and Discussion}

Characterization of AgNPS

Characterization of AgNPs is important to understand and control nanoparticles synthesis and applications. Various techniques are used for determination of different parameters. The studies of size, morphology and composition of the nanoparticles were performed by means of transmission and scanning electron microscopy (TEM, SEM), energy - dispersive spectroscopy (EDx) and X-ray diffraction analysis.

\section{Optical properties of AgNPs:}

The absorption spectrum of the prepared AgNPs was taken at different time intervals
$[13,14]$ after synthesis Fig. (1). It is solution after synthesis gives an absorbance peak at $425 \mathrm{~nm}$ due to plasmon resonance of the nanoparticles (Fig. 1a). The stability of the AgNPs the absorption spectra of nanoparticles was examined after 2 weeks (Fig. 1b) and 4 weeks (Fig. 1c) intervals. There is no change in the peak position even after storing for 4 weeks. The stable position of the absorbance peak $\left(\lambda_{\max }\right)$ indicates that the particles do not aggregate. The increase in absorbance value after storing for 4 weeks is indicative of increase in concentration of the nanoparticles through the generation of new particles. The aggregation of the particles could be avoided with the help of citrate anions. The AgNPs form negative screen due to the adsorbed citrate ions. The repulsive force of these negatively charged spheres prevents further aggregation.

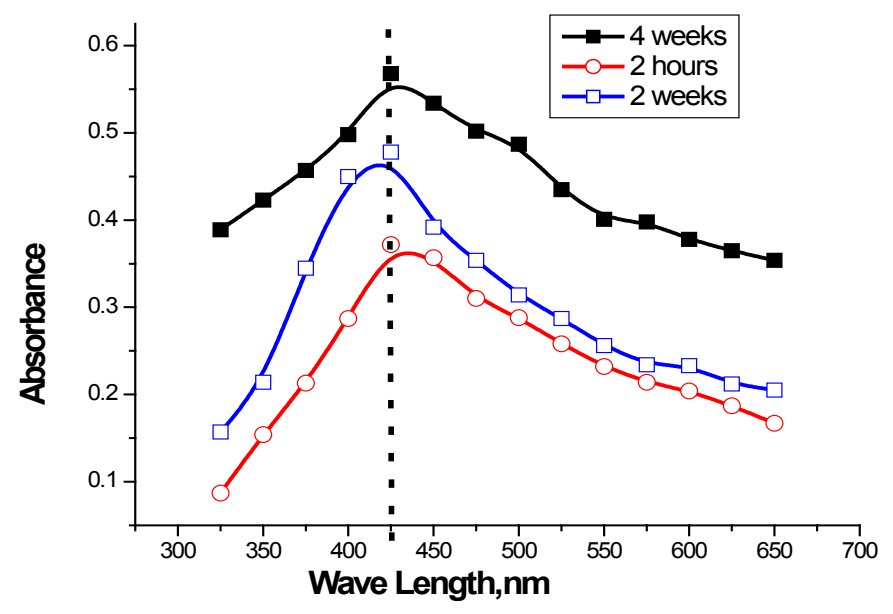

Fig. (1) UV-vs spectra of AgNPs [time after synthesis (a) 1h. (b) 2 weeks and (c) 4 weeks]. 
Transmission and scanning electron microscopy:

The size of AgNPs was obtained by TEM Fig. (2), the distribution range of AgNPs are approximately from $5 \mathrm{~nm}$ to $50 \mathrm{~nm}$. Although a few larger particles, the diameter of most particles $(99.2 \%)$ is less than $10 \mathrm{~nm}$. This indicates that the synthesized AgNPs are a narrow distribution of diameters and the average diameter of approximately $10 \mathrm{~nm}[13,15]$. Scanning electron microscopy has provided further insight into the morphology and size details of the synthesized nanoparticles. (Fig. 3) shows the SEM image of AgNPs. It seems that the sample consisted of a large quantity of dispersive nanoparticles with the average size of about 5-50 $\mathrm{nm}$. As it is clear in the SEM image, the nanoparticles are relatively uniform and seemed as quasi-spheres.

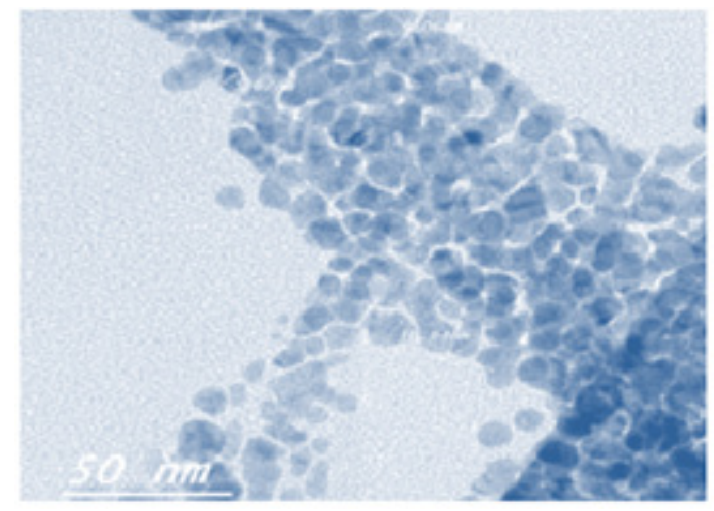

Fig. 2. TEM image of spherical silver nanoparticles

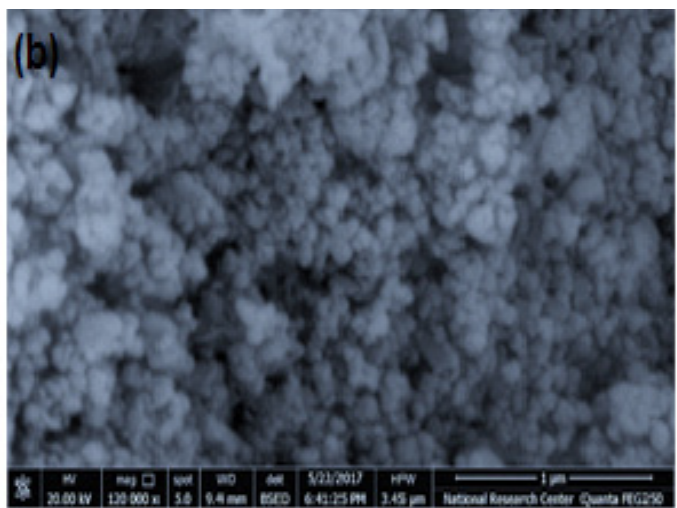

Fig. 3. SEM image of spherical silver nanoparticles

\section{Energy dispersive spectroscopy (EDX)}

The EDX analysis (Fig. 4), shows that the AgNPs consists of $\mathrm{Ag}, \mathrm{C}$, and $\mathrm{Cl}$ elements [16]. Results from Table (1), confirms the appearance of AgNPs. The peaks around $3.20,3.50$ and $3.70 \mathrm{KeV}$, are correspond to the binding energies of $\mathrm{Agl}_{\alpha}, \mathrm{Agl} \beta$ and $\operatorname{AgL} \beta_{2}$, respectively, while the peak near 1.0 $\mathrm{KeV}$ corresponding of carbon is observed. The carbon peak corresponds to the SEM holding grid. Throughout the scanning range of binding energies, no obvious peak belong to impurity is detected. The result indicates that the as synthesized product is composed of high purity AgNPs.

\begin{tabular}{lllll}
\hline Element & Weight \% & Atomic \% & Net Int. & Error \% \\
\hline Ck & 27.8 & 71.84 & 27.94 & 15.2 \\
Clk & 0.62 & 0.73 & 5.44 & 66.04 \\
AgL & 71.58 & 27.44 & 299.02 & 4.02 \\
\hline
\end{tabular}




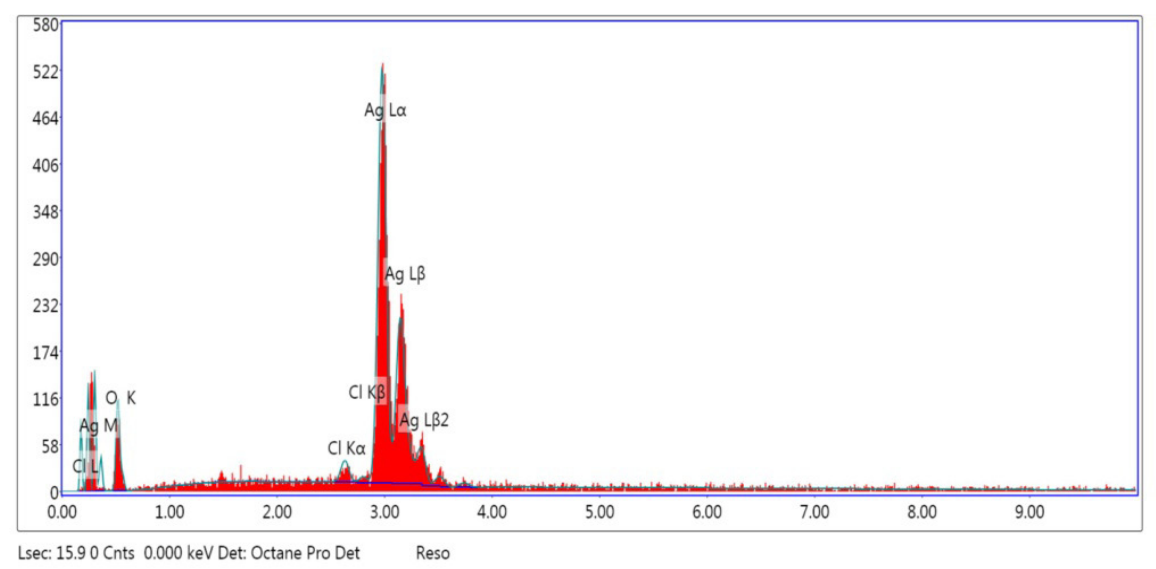

Fig. 4.EDX analysis of silver nanoparticles

\section{Fourier transform infrared spectroscopy (FTIR)}

Fig. 4 shows the infrared spectra of AgNPs prepared with sodium citrate. According to the literature $[15,17]$, the carbonyl stretch absorption as in citrate group is positioned between 1695 $\mathrm{cm}^{-1}$ and $1615 \mathrm{~cm}^{-1}$ (peak 11). Other observed bands at $2930 \mathrm{~cm}^{-1}$ (peak 8) and $2858 \mathrm{~cm}^{-1}$ (peak 9) are attributed to the asymmetric and symmetric stretching vibrations of $\mathrm{C}-\mathrm{H}$ bond, and at 3440 $\mathrm{cm}^{-1}$ (peak 7) assigned to -OH group of $\mathrm{H}_{2} \mathrm{O}$.

The formation of silver nanoparticles by donation of electrons from $\mathrm{O}$ to $\mathrm{Ag}$ or coordination between these atoms. Another blue shift of the absorption band appearing at 1487 and $1389 \mathrm{~cm}^{-1}$ (peak 12,13) was observed. This band displacement corresponds to the coordination of carbonyl oxygen with silver particles.

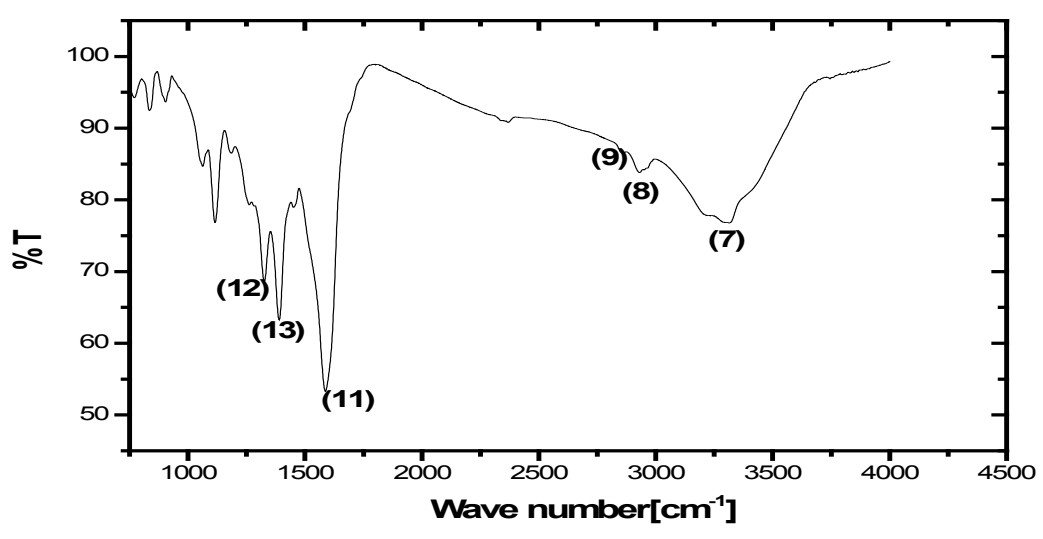

Fig. (5): FT-IR spectra of silver nanoparticles.

\section{Adsorption kinetics}

Several kinetic models such as pseudo-first order, pseudo-second-order, Elovich equation and the intraparticle diffusion model were applied for the experimental data at different temperatures
$[18,19]$. The amount of Ry2 dye adsorbed onto modified cotton fabric increased as the time increased at constant initial dye concentration and different temperature 60,75 and $90^{\circ} \mathrm{C}$.

The lagergren pseudo-first-order kinetic 
model is expressed as follows:

$\log \left(q_{e}-q_{t}\right)=\log q_{e-} k_{1} t / 2.303$

Where $q_{e}$ and $q_{t}$ are the amounts of dye sorbed at equilibrium and at time $\mathrm{t}(\mathrm{mg} / \mathrm{g}$ cotton $)$, respectively, and $\mathrm{k}_{1}$ is the equilibrium rate constant of pseudo-first-order sorption $\left(\mathrm{min}^{-1}\right)$. The plot of $\log \left(\mathrm{q}_{\mathrm{e}}-\mathrm{q}_{\mathrm{t}}\right)$ as a function of $\mathrm{t}$ (Fig. 6) provides the $\mathrm{k}_{1}$ and $\mathrm{q}_{\mathrm{e}}$ values. As show in (Table 4) for reactive yellow 2 at different temperatures. The correlation coefficients of reactive dye more than 96. However, the linearity is not good and the calculated value of $\mathrm{q}_{\mathrm{e}}$ cal is far lower than the experimental $q_{e}$ exp. This discrepancy shows that the adsorption of Ry2 dye, modified cotton fabric does not fit the pseudo-first-order kinetic model.

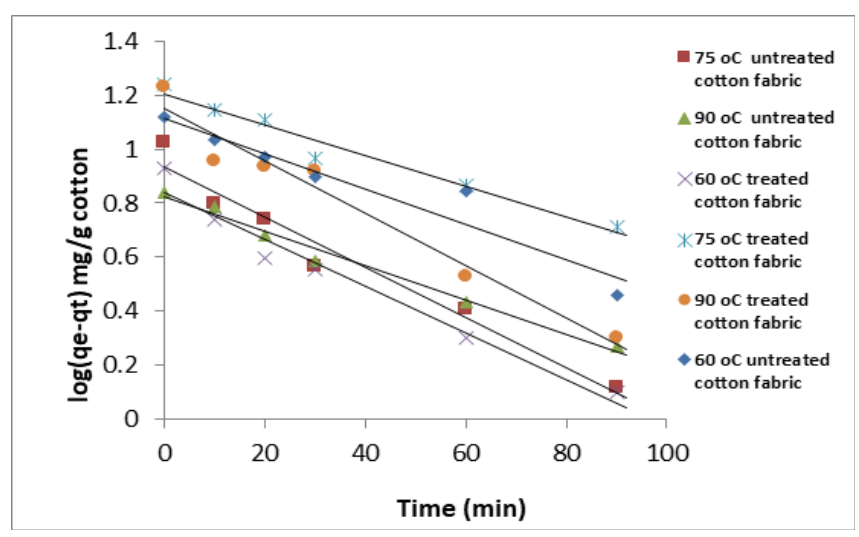

Fig. (6): Adsorption kinetics of the pseudo-first order model for the adsorption of reactive yellow 2 by untreated and treated cotton fabric at different temperatures $\left(60,75,90^{\circ} \mathrm{C}\right)$.

The pseudo-second-order kinetic model [20,21] can be expressed as follows:

$$
\mathrm{t} / \mathrm{q}_{\mathrm{t}}=1 / \mathrm{k}_{2}\left(\mathrm{q}_{\mathrm{e}}\right)^{2}+\mathrm{t} / \mathrm{q}_{\mathrm{e}}
$$

where $\mathrm{k}_{2}\left(\mathrm{~g} \mathrm{mg}^{-1} \mathrm{~min}^{-1}\right)$ is the rate constant for the pseudo-second-order kinetic model. The $\mathrm{q}_{\mathrm{e}}$ and $\mathrm{k}_{2}$ values were estimated from the slope and intercept of the linear plot of $t / q_{t}$ versus $t$ (Figure 7) at different temperatures. In general, the correlation coefficients are better $\left(r^{2}>98\right)$ and the adsorption capacity $(a) 2$ anrood varu wall with both experiment and calculated was observed in (Table 4) for reactive dye that the pseudo-secondorder model better represented the adsorption kinetics, suggesting that the adsorption process is indicative of a chemisorptions mechanism, which fits the experimental data better than the pseudo-first-order model. The pseudo-secondorder model is based on the assumption that the rate determining step may be a chemical sorption involving valence forces through sharing of electrons between adsorbent and adsorbate.

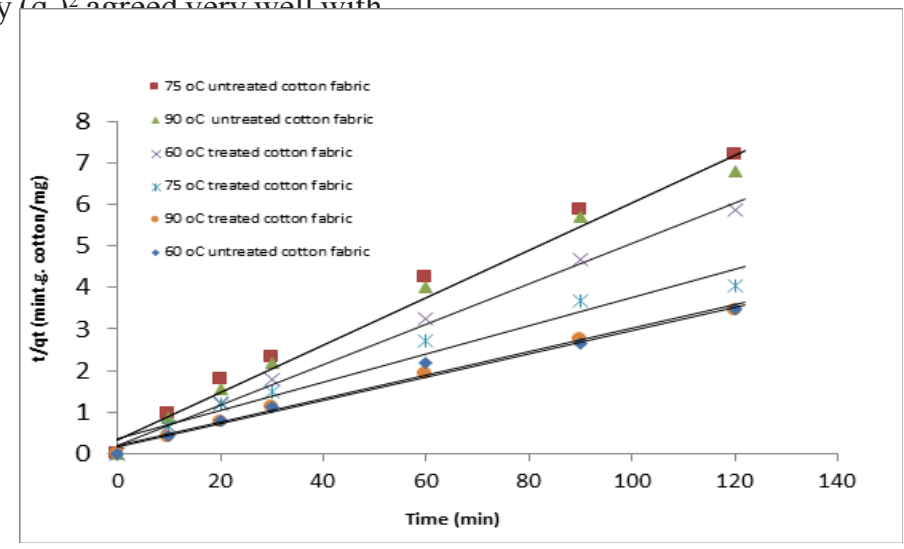

Fig. (7): Adsorption kinetics of the pseudo-second order model for the adsorption of reactive yellow 2 by untreated and treated cotton fabric at different temperatures $\left(60,75,90^{\circ} \mathrm{C}\right)$.

Egypt. J. Chem. Vol. 63, No. 4 (2020) 
The Elovich equation was first applied to the chemisorptions kinetics of gases on solids [22,23], it has also been successfully used in recent years to describe the adsorption of the solutes from a liquid solution. The linear form of the Elovich equation is given as :

$$
\mathrm{q}_{\mathrm{t}}=1 / \beta \ln (\alpha \beta)+1 / \beta \operatorname{Lnt}
$$

Where $\alpha$ is the initial adsorption rate constant ( $\mathrm{mg} /(\mathrm{g}$ min) and the parameter $\beta$ is the desorption constant related to the extent of surface coverage and activation energy for chemisorption ( $\mathrm{g} / \mathrm{mg})$.
The validity of the Elovich equation suggests that a chemisorptions (chemical reaction) mechanism is likely rate-controlling in the processes [24]. The values of $\alpha$ and $\beta$ can be calculated from the plot of $\mathrm{q}_{\mathrm{t}}$ against $\ln \mathrm{t}$ (Figure 8) and the constant are given (Table 4 ). The correlation coefficients of dye not more than (0.98).

The correlation coefficients $\left(\mathrm{r}^{2}\right)$ of the pseudosecond-order model were higher than the pseudofirst-order and Elovich equation model (Table 9). It could be concluded that the mechanism of adsorption was a pseudo-second- reaction.

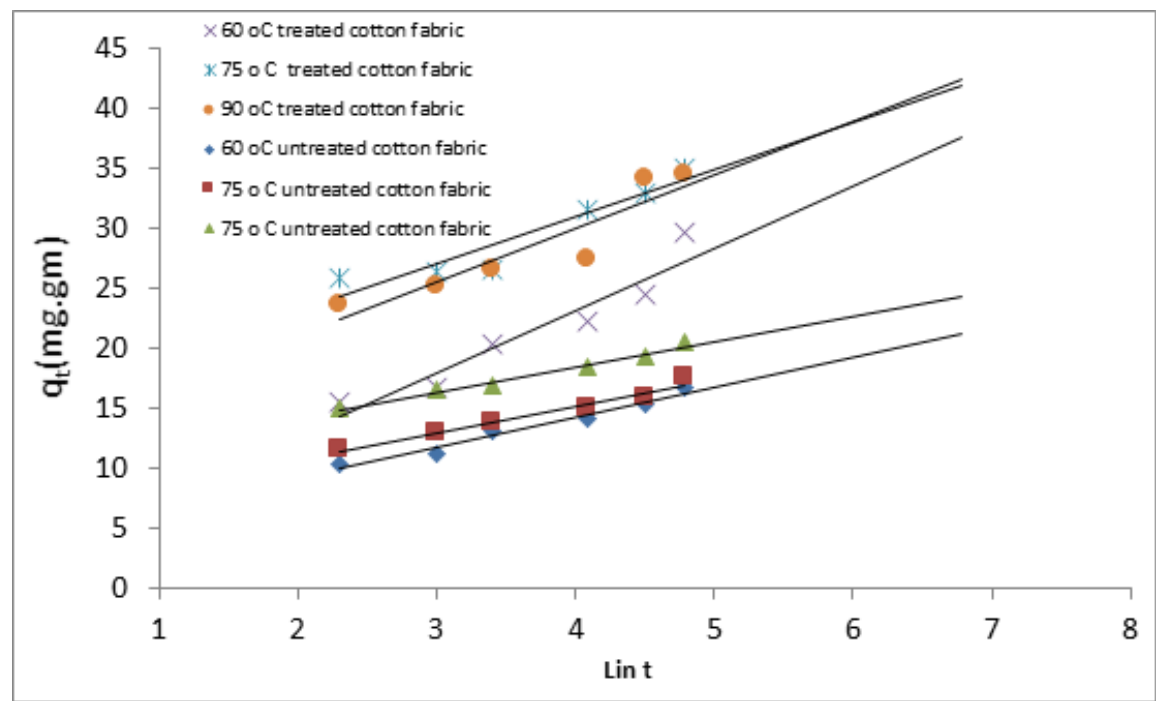

Fig. (8): Elovich adsorption model of reactive yellow 2 on AgNPs by untreated and treated cotton fabric at different temperatures $\left(60,75,90^{\circ} \mathrm{C}\right)$.

The possibility of intraparticle diffusion resistance affecting adsorption was explored by using the intraparticle diffusion model $[25,26]$ as :

$$
\mathrm{q}_{\mathrm{t}}=\mathrm{K}_{\mathrm{i}} \mathrm{t}^{1 / 2}+\mathrm{C}
$$

Where $\mathrm{C}$ is the intercept and $\mathrm{K}_{\mathrm{i}}$ the intraparticle diffusion rate constant $\left(\mathrm{mg} / \mathrm{g} \mathrm{min}^{1 / 2}\right.$ ). According to this model, plot of $\mathrm{q}_{\mathrm{t}}$ versus $\mathrm{t}^{1 / 2}$ (Figure 9) should be linear if intraparticle diffusion is involved in the adsorption process. If the line passes through the origin, intraparticle diffusion is the rate controlling step. If not, the intraparticle diffusion is not the only rate-Limiting step. This also confirms that adsorption of Ry2 on the cotton is a multi-step process, involving Egypt. J. Chem. Vol. 63, No. 4 (2020) adsorption on the external surface and diffusion into the interior [27]. From (Figure 9), at all conditions, the sorption process tends to be followed by two phases. It was found that an initial linear portion ended with a smooth curve followed by a second linear portion. The two phases in the intraparticle diffusion plot suggest that the sorption process proceeds by surface sorption and the intraparticle diffusion. The initial curved portion of the plot has been defined as the intraparticle diffusion parameter $\left(\mathrm{K}_{\mathrm{i}}\right)$. The correlation coefficients (r) are not more than 0.98 as shown in (Table 4). The observed increase in $\mathrm{K}_{\mathrm{i}}$ values with increasing the temperature promote the pore diffusion in sorbent particles (cotton fabric) and enhance the intraparticle 
diffusion rate. It is likely that a large number of ions

diffuse into the pore before being adsorbed ${ }^{(26)}$.

TABLE (4). Kinetic parameters for the adsorption of C.I. reactive yellow 2 (RY2) onto cotton fabric at different temperatures.

\begin{tabular}{|c|c|c|c|c|c|c|c|c|c|c|c|c|c|}
\hline \multirow[b]{2}{*}{ Sample } & \multirow[b]{2}{*}{$\begin{array}{l}\text { Temp. } \\
{ }^{\circ} \mathrm{C}\end{array}$} & \multirow[b]{2}{*}{$\begin{array}{c}\mathrm{q}_{\mathrm{e}}, \\
\text { exp. } \\
(\mathrm{mg} / \mathrm{g})\end{array}$} & \multicolumn{3}{|c|}{$\begin{array}{l}\text { Pseudo first-order } \\
\text { model }\end{array}$} & \multicolumn{3}{|c|}{$\begin{array}{l}\text { Pseudo second-order } \\
\text { model }\end{array}$} & \multicolumn{3}{|c|}{ Elovich equation model } & \multicolumn{2}{|c|}{$\begin{array}{c}\text { Intraparticle } \\
\text { diffusion model }\end{array}$} \\
\hline & & & $\begin{array}{l}\mathrm{K}_{1} \times 10^{2} \\
\left(\mathrm{~min}^{-1}\right)\end{array}$ & $\begin{array}{c}\mathrm{q}_{\mathrm{e} 1}, \\
\text { cal. } \\
(\mathrm{mg} / \mathrm{g})\end{array}$ & $\mathbf{r}^{2}$ & $\begin{array}{c}\mathrm{K}_{2} \times 10^{-3} \\
(\mathrm{~g} / \mathrm{mg} \\
\mathrm{min})\end{array}$ & $\begin{array}{c}\mathrm{q}_{\mathrm{e} 2 \mathrm{e}} \\
\text { cal. } \\
(\mathrm{mg} / \mathrm{g})\end{array}$ & $\mathbf{r}^{2}$ & $\begin{array}{c}\alpha \\
(\mathrm{mg} / \mathrm{g} \\
\mathrm{min}) \\
\end{array}$ & $\begin{array}{c}\beta \\
(\mathrm{g} / \mathrm{mg})\end{array}$ & $\mathbf{r}^{2}$ & $\begin{array}{c}\mathbf{K}_{\mathrm{i}} \mathbf{m g} / \\
\mathbf{g m}\end{array}$ & $\mathbf{r}^{2}$ \\
\hline Untreated & 60 & 16.65 & 2.14 & 8.56 & 0.98 & 4.77 & 18.70 & 0.99 & 3.39 & 0.27 & 0.99 & 0.50 & 0.99 \\
\hline cotton & 75 & 17.60 & 1.46 & 6.63 & 0.99 & 5.21 & 17.78 & 0.99 & 39.65 & 0.29 & 0.99 & 0.70 & 0.99 \\
\hline fabric & 90 & 20.45 & 1.99 & 6.91 & 0.98 & 5.94 & 20.90 & 0.99 & 101.49 & 0.34 & 0.99 & 0.85 & 0.99 \\
\hline Treated & 60 & 29.55 & 1.31 & 16.07 & 0.98 & 5.21 & 31.30 & 0.98 & 164.02 & 0.40 & 0.98 & 1.11 & 0.99 \\
\hline cotton & 75 & 34.90 & 2.24 & 14.17 & 0.97 & 8.16 & 35.35 & 0.99 & 278.66 & 0.47 & 0.99 & 1.29 & 0.99 \\
\hline fabric & 90 & 34.40 & 1.51 & 13.09 & 0.96 & 11.21 & 38.17 & 0.99 & 395.44 & 0.53 & 0.98 & 1.80 & 0.99 \\
\hline
\end{tabular}

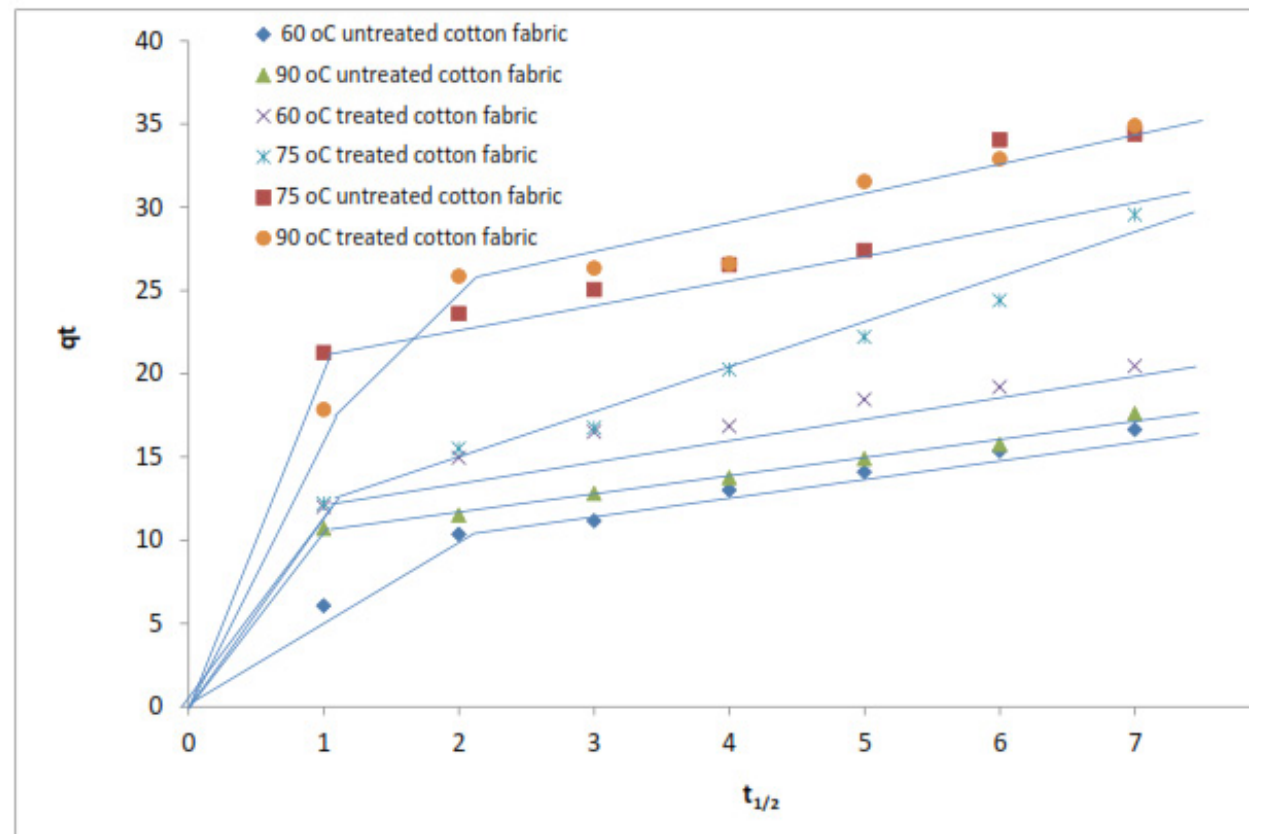

Fig. (9): Intraparticle diffusion model of reactive yellow 2 on AgNPs by untreated and treated cotton fabric at different temperatures $\left(60,75,90^{\circ} \mathrm{C}\right)$.

Adsorption thermodynamics:

The pseudo-second-order rate constant of dye adsorption is expressed as a function of temperature by Arrhenius type:

$$
\mathrm{LnK}=\mathrm{LnA}-\mathrm{Ea} / \mathrm{RT}
$$

Where $\mathrm{K}$, refer to either the rate constants $\left(\mathrm{K}_{2}\right)$ of pseudo-second-order model, Ea is the activation energy of sorption $(\mathrm{KJ} / \mathrm{mole}), \mathrm{R}$ is the gas constant $8.314(\mathrm{~J} / \mathrm{mol} \mathrm{K}), \mathrm{T}$ is the absolute temperature $\left(\mathrm{K}^{\circ}\right)$ and $\mathrm{A}$ the Arrhenius factor which is a temperature independent factor, respectively. The activation energy is determined from the slope of the plot of $\left(\mathrm{Ln} \mathrm{K}_{2}\right)$ versus $(1 / \mathrm{T})$ for reactive yellow 2 on unmodified and modified cotton fabric at different temperatures 60, 75 and $90^{\circ}$. The magnitude of the activation energy yields information on whether the adsorption process is mainly physical or chemical reported that the activation energy of physisorptoin is 
normally not more than $4.20 \mathrm{KJ} / \mathrm{mol}$. [28]. The value of activation energies (Ea) given in (Table 5 ) confirm the nature of chemisorption process for Ry2 adsorbed on cotton fabric.

The thermodynamic parameters such as change in standard free energy $\left(\Delta G^{\circ}\right)$, enthalpy $\left(\left(\Delta \mathrm{H}^{\circ}\right)\right.$ and entropy $\left(\left(\Delta \mathrm{S}^{\circ}\right)\right.$ were determined by using the following equations:

$$
\begin{aligned}
\ln \mathrm{K}_{\mathrm{c}} & =\Delta \mathrm{S}^{\circ} / \mathrm{R}-\Delta \mathrm{H}^{\circ} / \mathrm{RT} \\
\Delta \mathrm{G}^{\circ} & =\Delta \mathrm{H}^{\circ}-\mathrm{T} \Delta \mathrm{S}^{\circ}
\end{aligned}
$$

Where $\mathrm{R}(8.314 \mathrm{~J} / \mathrm{mol} \mathrm{K})$ is the gas constant, $\mathrm{R}\left(\mathrm{K}^{\circ}\right)$ the absolute temperature and $\mathrm{K}_{\mathrm{c}}(1 / \mathrm{g})$ is the standard thermodynamic equilibrium constant defined by $\mathrm{q}_{\mathrm{e}} / \mathrm{C}_{\mathrm{e}}$. By plotting a graph of $\ln \mathrm{K}_{\mathrm{c}}$ versus $1 / \mathrm{T}$ the values $\Delta \mathrm{H}^{\circ}$ and $\Delta \mathrm{S}^{\circ}$ can be estimated from the slopes and intercepts. (Table 5) shows the positive $\Delta \mathrm{G}^{\circ}$ value in case of unmodified cotton fabric suggests that adsorption reactions require energy to convert reactants into products. The $\Delta \mathrm{G}^{\circ}$ value determines the rate of the reaction, rate increases as $\Delta \mathrm{G}^{\circ}$ decreases, and hence the energy requirement is fulfilled. While the positive $\Delta \mathrm{H}^{\circ}$ obtained indicated that the dye adsorption process is a spontaneous and an endothermic. The entropy change $\Delta \mathrm{S}^{\circ}$ shows the extent of the reduced freedom of dye molecules after the completion of dyeing and represents the entropy difference of the dye molecules within the fiber. The decrease in the entropy values may explain the decrease in randomness after the dyeing process, Table (5). The entropy change shows negative values in dyeing process, because adsorbed dyes become more ordered within fiber molecules than the dyes in solution. Therefore, the value of the entropy change can be regarded as the measure of immobility of dyes within the fiber [29]. The positive values of $\mathrm{Ea}$, and $\Delta \mathrm{H}^{\circ}$ indicate the presence of an energy barrier in the adsorption process and endothermic process [26].

TABLE (5). Thermodynamic parameters of reactive yellow 2 adsrobed on cotton fabric before and after modification

\begin{tabular}{ccccccc}
\hline Sample & Temp. $^{\circ} \mathbf{C}$ & Temp. $\mathbf{K}^{\circ}$ & $\mathbf{E a}(\mathbf{K J} / \mathbf{m o l})$ & $\Delta \mathbf{H}^{\circ}(\mathbf{K J} / \mathbf{m o l})$ & $\Delta \mathbf{S}^{\circ}(\mathbf{J} / \mathbf{m o l} \mathbf{~ k})$ & $\Delta \mathbf{G}^{\circ}(\mathbf{K J} / \mathbf{m o l})$ \\
\hline $\begin{array}{c}\text { Uncreated cotton } \\
\text { fabric }\end{array}$ & 60 & 333 & & & & +16.03 \\
& 75 & 348 & +29.93 & +14.78 & -3.74 & +16.08 \\
& 90 & 363 & & & +16.14 \\
Treated cotton fabric & 60 & 333 & & & +5.84 \\
& 75 & 348 & +23.75 & +5.15 & -2.08 & +5.87 \\
& 90 & 363 & & & +5.91 \\
\hline
\end{tabular}

Effect of AgNPs treatment on resistance against Microbes:

Silver has been known since antiquity as a popular agent to fight against infections and prevent spoilage. But due to emergence of antibiotic resistant microorganisms over the last decade use of silver compounds has been declined remarkably [30]. Various theories have been proposed to explain its antimicrobial activity; however, it's mode of action is yet not fully elucidated. The most accepted mechanism is on the basis of their interaction with cell membrane causing extensive cell surface alternations and permeability, leading to intracellular leakage of cytoplasm and finally death of microorganism. Silver binds to the bacterial cell wall and cell membrane and inhibits the respiration process causes microorganism structural changes, and then inhibits the metabolic pathway through producing reactive oxygen species [31]. Other mechanism suggest the antimicrobial activity due to interaction of silver nanoparticles with the sulphur and phosphorus of the DNA, leading to or inducing problem in its replication ability and eventual cell death [32].

The antibacterial property of pretreated cotton samples with AgNPs was analyzed against gram positive and negative bacteria. The pretreated cotton samples with AgNPs presented an inhibition zone around the dyed sample while the untreated cotton sample that only dyed with reactive yellow 2 did not reveal antibacterial 
properties. The average width of an inhibition zone is presented in (Table 6).

TABLE (6). Effect of AgNPs on resistance towards bacterial attack

\begin{tabular}{l} 
Sample $\begin{array}{c}\text { Gram-positive bacteria } \\
\text { Staphyloccus } \\
\text { aureus ATCC } \\
25923\end{array}$ \\
\hline 1 \\
Bacillus subtilis \\
ATCC6635
\end{tabular}

\section{References}

1. Haggag K., El-Molla M. M. and Mahmoued Z. M., "Dyeing of cotton fabrics using reactive dyes by microwave irradiation technique". Indian J. Fiber Text. Res. 39, 406-410 (2014).

2. Chattopadhyay D. P. and Patel B. H.,'Improvement in physical and dyeing properties of natural fibres through pre-treatment with silver nanoparticles". Indian J. Fibre Text. Res. 34, 368-373 (2009).

3. Asem A. Mohamed, M.K. Zahran , M.H. ElRafie." Biogenesis of Silver Nanoparticles Feasible for Industrial Application Using Yeastfungi Secreted Enzymes and Proteins. Egypt. J. Chem. The 8th. Int. Conf. Text. Res. Div., Nat. Res. Center, Cairo (2017), 49 - 61 (2017)

4. Gokarneshan N., Gopalakrishnan P. P. and Jeyanthi

\begin{tabular}{|c|c|c|c|}
\hline \multicolumn{2}{|c|}{ Gram-negative bacteria } & \multicolumn{2}{|c|}{ Yeast and fungi** } \\
\hline $\begin{array}{l}\text { almonella } \\
\text { himurium } \\
\text { CC } 14028\end{array}$ & $\begin{array}{l}\text { Escherichia coli } \\
\text { ATCC } 25922\end{array}$ & $\begin{array}{l}\text { Candida albicans } \\
\text { ATCC } 10231\end{array}$ & $\begin{array}{c}\text { Aspergillus } \\
\text { fumigatus }\end{array}$ \\
\hline $7 \mathrm{~L}$ & -- & -- & 4L-- \\
\hline $10 \mathrm{~L}$ & -- & -- & 10L-- \\
\hline
\end{tabular}

5. nanostructures modified multifunctional cotton fabrics". Appl Nanosci. 2 119-126 (2012).

1. 6. Vigo T.,"Antibacterial fiber treatments and disinfection". Text. Res. J. 51 454-465 (1981).

7. Gao Y. and Cranston R.,"Recent advances in antimicrobial treatments of textiles". Text. Res. J. 78(1) 60-72 (2008).

8. Reddy K. M., Feris K., Bell J., Wingett D. G., Hanley C. and Punnoose A.,"Selective toxicity of zinc oxide nanoparticles to prokaryotic and eukaryotic systems". Appl. Phys. Lett. 90:2139021-213902-3 (2007).

9. E. A. El-Alfy, M. Attya and M.F. Shaaban "Treatment of Cotton Fabrics to Inhibit Bacterial Effect of Some Microorganisms Part I: Using Separate Nano Antibacterial Agents" Egypt. J. Chem. 58(6), pp. 671-680 (2015).

10. Hussien A.M., Gawish S. M., Mosleh S. , Ramadan A. M. Sayed G .H. Antimicrobial Polypropylene Loaded by Cubic Cuprous Oxide Micro Particles. Egypt. J. Chem. 62(6), 1447 - 1455 (2019)

11. Judd D. B. and Wyszenki G., Color in Business Science and Industry, $3^{\text {rd }}$ ed., ( Wiley series in pure and applied optics, New York), 1975.

12. Islam M., Faisal Md A., Weilin Xu, Faridul Hasan K. M. and Hridam D.,'Improvement the fastness properties of cotton fabric through the implementation of different mordanting agents dyed with natural dye extracted from marigold". American J. of Polymer Sci. and Eng., 4 , 8-16 (2016).

13. Natsuki J. and Abe T.,"Synthesis of pure colloidal

Egypt. J. Chem. Vol. 63, No. 4 (2020) 
silver nanoparticles with high electroconductivity for printed electronic circuits :The effect of amines on their formation in aqueous media". J. Colloid Interf. Sci. 359 , 19-23 (2011).

14. Yamamoto S., FujiwaraK K. and Watari H.,"Diffraction and spectroscopic methods in electrochemistry". Anal. Sci., 20 , 1347-1352 (2004).

15. Fouda A. and Shaheen Th. I.,"Silver nanoparticles :Biosynthesis, characterization and application on cotton fabrics". M. R. J. I., 20 (1), 1-14 (2017).

16. Sciemmeca M., Bischetti S., Lamsira H. K., Bonfiglio R. and Bonanno E., "Energy dispersive X-ray (EDX)microanalysis: Apowerful tool in biomedical research and diagnosis". European Journal of Histochemistry, 62:2841 1-10 (2018).

17. Debnath D., Kim C., Kim H. and Geckeler K. E., Macromol. Rapid commun. 31 (6), 549 (2010).

18. Alver E. and Metin A. U.,"Anionic dye removal from aqueous solution using modified zeolite: Adsorption kinetics and isotherm studies". Chem. Eng. J., 200-202, 59-67 (2012).

19. Ho Y. S. and Mckay G.,"Pseudo-second order model for sorption process". Process Biochem. , 34, 451-65 (1999).

20. Srivastava V. C. and Mishra I. M., "Onto activated carbon :study of sorption behavior through characterization and kinetics". Chem. Eng. Process , 47 (8), 1269-1280 (2008).

21. Ofomaja A. E., Naidoo E. B. and Modise S.J., "Kinetic and Pseudo-second order modeling of lead biosorption onto pine cone powder". Industrial and Eng. Chem. Res., 49 , 2562- 2572 (2010).

22. Zeldowitsch J., Acta Physiochem. URSS., 1, 364449 (1934).

23. Raji F. and Pakizeh M., "Kinetic and thermodynamic studies of $\mathrm{Hg}(\mathrm{II})$ adsorption onto MCM-41 modified by $\mathrm{ZnCl}_{2}$ ", J. Applied Surface Science, 301 , 568 (2014).

24. Chang M. Y. and Juang R. S., Colloids Surf.. A 269, 35-46 (2005)

25. Pang X. Y. and Gong F., "Study on the adsorption kinetics of acid red 3Bon expanded graphite". $J$.

Egypt. J. Chem. Vol. 63, No. 4 (2020)
Chem., 5 , 802-809 (2008).

26. Ismail L. F. M., Sallam H.B., Abo Farha S.A., Gamal A. M. and Mahmoud G .E. A., "Cationic dyeing and antimicrobial finishing of treated acrylic fabric :Determination of equilibrium, kinetics and thermodynamics parameters of BR2, nano-BR and BR2 dye coated AuNPs". Molecular and Biomolecular Spectroscopy, (2014).

27. Dogan M., Abak H. and Alkan M., "Adsorption of methylene blue onto hazelnut shell: kinetics, mechanism and activation parameters". J. Hazard. Mater., 164 , 172-181 (2009).

28. Unuabonath E. L., Adebowale K. O. and Owolabi B. I., "Kinetic and thermodynamic studies of the adsorption of lead(II) ion onto phosphate modified kaolinite clay”. J. of Hazardous Material, 144 , 386 (2007).

29. Kumaresan M., Palanisamy P. N. and Kumar P. E., "Application of eco-friendly natural dye on cotton using combination of mordants". Indian J. of Fiber and Text. Res., 37, 194-198 (2012).

30. Rai M., Yadav A. and Gade A., "Silver nanoparticles as a new generation of antimicrobials". Biotechnol. $A d v ., 27(1), 76-83$ (2009).

31. Prabhu S. and Poulose E.K., "Silver nanoparticles mechanism of antimicrobial action"., Int. Nano. Lett., 2(1), 32 (2012)

32. Eckhardt S., Brunetto P. S., Ganon J., Priebe M., Giese B. and Fromm k. m., "Nanobio silver :Its interaction with peptides and bacteria, and its uses in medicine". Chem. Rev., 113 (7), 4708-4754 (2013). 
تحسين الصباغة والخصائص المضادة للميكروبات للاقمشة القطنية من خلال معالجتها بجسيمات

الفضة النانونية

'الشيماء حسن محمد جمعة ', نورا محمد هلال '، ' , سامية الحسينى أبو فرحة'

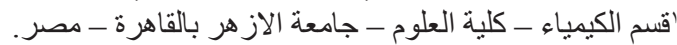
r جامعة الطائف ـالكلية الجامعية برنية_المملكة العربية السعودية.

مركب الفضة النانونية يمكن تحضيره بو اسطة الإختز ال الكيميائى لمحلول ملح الفضة. وتم إجر اء بعض التحاليل لتوصيف

شكل الجزيئات النانونية النى نت الحصول عليها مثل: SEM

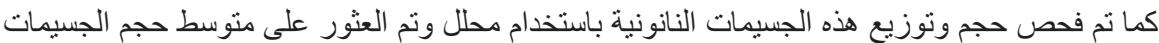

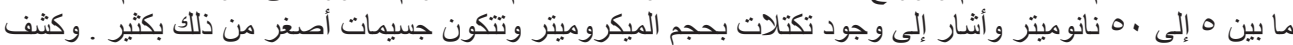

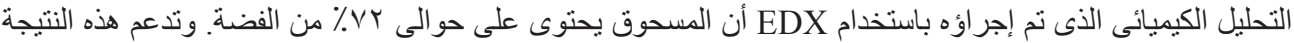

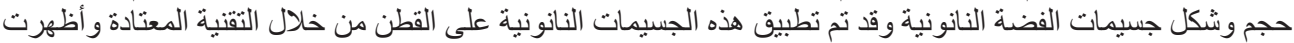

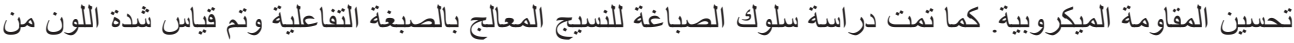

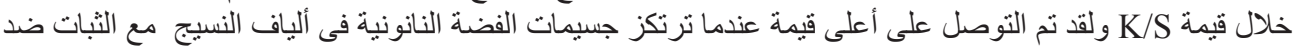

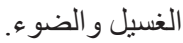

